\title{
Profitability As Determining Factor to Anticipate Company Bankruptcy
}

\author{
ANA KADARNINGSIH ${ }^{1}$, VICKY OKTAVIA ${ }^{2}$, T.R. FAHSUL FALAH ${ }^{3}$, YENITA SANDRA SARI ${ }^{4}$ \\ ${ }^{1}$ Economics and Business Department, DIAN NUSWANTORO UNIVERSITY, INDONESIA. \\ E-mail: ana.kadarningsih@dsn.dinus.ac.id \\ ${ }^{2}$ Economics and Business Department, DIAN NUSWANTORO UNIVERSITY, INDONESIA. \\ E-mail: Vicky.udinus@gmail.com \\ ${ }^{3}$ Doctoral Program of Management, PASUNDAN UNIVERSITY, INDONESIA. E-mail:tr.ffalah@gmail.com \\ ${ }^{4}$ Environment Technology, KEBANGSAAN UNIVERSITY, INDONESIA. E-mail:yenitasandra@gmail.com
}

\begin{abstract}
The purpose of this study is to find out the effect of liquidity, leverage, operating capacity on financial distress through profitability as intervening variable. The population of this study is manufacturing companies listed on the IDX over the sampling. Based on the technique purposive sampling, obtained sample of 123 data from 54 manufacturing companies on IDX list from 2016 until 2018. This study uses path analysis using Warp PLS 5.0 software and Sobel test to find significancy of mediating variable. The results of this study indicate that profitability and leverage have a significant effect on the financial distress of manufacturing companies. Meanwhile, liquidity, and operating capacity have no effect on the financial distress of manufacturing companies. The intervening test confirmed that profitability have partial mediation role for relationship between liquidity, leverage, operating capacity with financial distress. Furthermore, the Sobel test also confirmed that profitability can significantly mediate the effect of liquidity, leverage and operating capacity on financial distress.
\end{abstract}

Keywords: Financial distress; Profitability; Manufacturing Companies.

JEL Classification: G23, G33, L60

Received: June 05, 2021

Accepted: September 27, 2021 


\title{
La Rentabilidad como Factor Determinante para Anticipar la Quiebra de la Empresa
}

\author{
ANA KADARNINGSIH ${ }^{1}$, VICKY OKTAVIA ${ }^{2}$, T.R. FAHSUL FALAH ${ }^{3}$, YENITA SANDRA SARI $^{4}$ \\ ${ }^{1}$ Economics and Business Department, DIAN NUSWANTORO UNIVERSITY, INDONESIA. \\ E-mail: ana.kadarningsih@dsn.dinus.ac.id \\ ${ }^{2}$ Economics and Business Department, DIAN NUSWANTORO UNIVERSITY, INDONESIA. \\ E-mail: Vicky.udinus@gmail.com \\ ${ }^{3}$ Doctoral Program of Management, PASUNDAN UNIVERSITY, INDONESIA. E-mail: tr.ffalah@gmail.com \\ ${ }^{4}$ Environment Technology, KEBANGSAAN UNIVERSITY, INDONESIA. E-mail: yenitasandra@gmail.com
}

\begin{abstract}
RESUMEN
El propósito de este estudio es conocer el efecto de la liquidez, el apalancamiento y la capacidad operativa sobre las dificultades financieras a través de la rentabilidad como variable interviniente. La población de este estudio son las empresas de fabricación que figuran en el IDX sobre el muestreo. Con base en la técnica de muestreo intencional, se obtuvo una muestra de 123 datos de 54 empresas manufactureras en la lista IDX desde 2016 hasta 2018. Este estudio utiliza el análisis de ruta utilizando el software Warp PLS 5.0 y la prueba de Sobel para encontrar la significancia de la variable mediadora. Los resultados de este estudio indican que la rentabilidad y el apalancamiento tienen un efecto significativo sobre las dificultades financieras de las empresas manufactureras. Mientras tanto, la liquidez y la capacidad operativa no tienen ningún efecto sobre las dificultades financieras de las empresas manufactureras. La prueba interviniente confirmó que la rentabilidad tiene un papel de mediación parcial para la relación entre liquidez, apalancamiento, capacidad operativa con problemas financieros. Además, la prueba de Sobel también confirmó que la rentabilidad puede mediar significativamente el efecto de la liquidez, el apalancamiento y la capacidad operativa sobre las dificultades financieras.
\end{abstract}

Palabras clave: Problemas financieros; Rentabilidad; Empresas de fabricación.

Clasificación JEL: G23, G33, L60 


\section{Introduction}

Finance is an important factor in maintaining the stability of a company for profit. If the company experiences financial difficulties, the company will take actions that can restore its original financial position. The company should be able to take actions to anticipate financial difficulties such as financial analysis and prediction. Financial prediction analysis is a way of identifying financial performance so as to find the most important indicators that lead to potential bankruptcy or not due to financial distress experienced by the company.

Financial difficulties due to financial pressures can cause a company to be delisted from the Indonesia Stock Exchange. Delisting occurs when the shares of a company listed on the Indonesia Stock Exchange whose listing does not meet the requirements due to a decrease in criteria., then the shares can be issued in the listing listed on the Exchange. According to IDX data for 2018, IDX delisted 4 manufacturing companies, namely Dwi Aneka J.K Corp., Tbk (DAJK), Truba Alam M.E Corp, Tbk (TRUB), PT Jaya Pari Steel, Tbk (JPRS), and PT Taisho Pharmaceutical Indonesia, Tbk (SQBB). Delisting occurred because the four companies went bankrupt after failing to pay debts.

The phenomenon of company delisting in 2018 shows that financial difficulties have not been resolved, so bankruptcy is very likely to occur. Since August 2020 the manufacturing sector experienced a very strong contraction where utility and productivity decreased drastically by up to $40 \%$. Whereas before the pandemic, the average utilization of manufacturing companies could reach 76.29\% (CNBC Indonesia, 2020). Financial distress occurs before bankruptcy. The ability to predict bankruptcy will benefit many parties, especially creditors and investors.

Many factors affect financial distress, such as the level of leverage, liquidity, profitability, activity ratios, managerial ownership, independent board of commissioners, audit committee, and company size (Saputri \& Asrori, 2019; Antikasari \& Djuminah, 2017; Jamal \& Shah, 2017). One of the factors that influence financial distress is profitability. The profitability ratio shows the company's ability to create net income by using its own capital for the benefit of owners and investors (Erni, 2019). The higher the profitability ratio, the more effective the company is in generating profits by utilizing its assets, so that the possibility of financial difficulties is smaller (Ardianto \& Prasetyono, 2011). The following is the relationship between profitability and financial distress in manufacturing companies listed on the IDX from 2017-2018:

Figure 1 The Relationship between Profitability and Financial Distress in Manufacturing Companies in 20172018

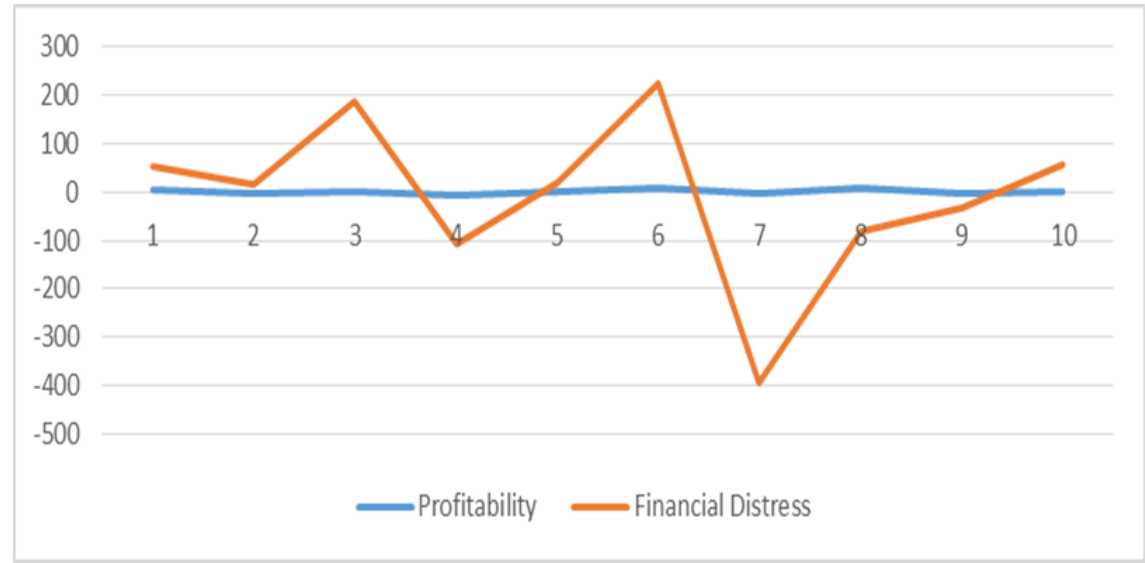

Source: Indonesia Stock Exchange, 2018

Figure 1 above shows that the profitability of manufacturing companies listed on the IDX from 20172018 is relatively stable, but predictions of bankruptcy (financial distress) are unstable. This means that stable profitability cannot guarantee that a manufacturing company will experience a potential bankruptcy. 


\section{Literature Review}

One of the important factors for investors is the long-term viability of the company or the absence of indications of bankruptcy. According to Brigham and Houston (2014) signal theory is a signal that can show investors see the company's expectations. This signal is in the form of information that provides an overview, description, record of the company's past and future. This signal is very important for investors for investment decision making. Signaling theory provides a positive signal that can increase the value of the company. One of the positive signals is the company's ability to pay off its obligations in the future (Hidayat \& Meiranto, 2014). Financial distress can be interpreted as the emergence of signals or early symptoms of bankruptcy experienced by a company. (Pulungan, 2017).

Liquidity is how far the company's ability to pay its short-term obligations by immediately (Dianova \& Nahumury, 2019). The liquidity ratio is reflected by the length of time inventory turned into cash. The most liquid current asset is cash, because cash can be used quickly to meet the company's shortterm obligations. The company's potential to experience financial difficulties will be smaller if the company is able to settle its short-term obligations with the available funds (Almilia \& Kristijadi, 2003). There are four determinants to measure liquidity, namely amount of cash, amount of receivable, inventory amount and amount of debt (Taurista et.al, 2018). Research results from Moch. et.al (2019), Amanda \& Tasman (2019), Kartika \& Hasanudin (2019), Putri \& Puryandani (2020), and Zhafirah \& Majidah (2019) said that liquidity has a significant negatively impact on financial distress or bankruptcy prediction.

Leverage arises from activities take advantage of debt as funds from third parties (Cinantya \& Merkusiwati, 2015). If the company's liabilities are lower than the company's total assets, the company is able to utilize its assets in paying off its obligations so that financial difficulties do not occur. However, if the total assets are lower than the company's liabilities, there will be financial difficulties for the company (Putri \& Merkusiwati, 2014). Research by Antikasari \& Djuminah (2017) proves that when the debt ratio is high, the presentation of companies experiencing financial distress will increase. Previous studies stated that leverage has a positively significant effect on financial distress (Dalci, 2018). Another result of previous research found that debt policy have negative and no significant impact on profitability (Lumapow \& Tumiwa, 2020). Leverage reflects how much a company uses debt as capital to finance assets. The company will benefit if most of its capital comes from debt, because interest on debt will reduce the tax burden so that the proportion of net income is high (Maharani \& Fuad, 2020). Leverage have statistically significant impact on profitability (Ahmad et al., 2015); (Alarussi \& Alhaderi, 2018).

Operating Capacity is commonly referred to as total asset turnover. High total asset turnover shows the greater effectiveness of the company when it uses its assets to create trade to provide big profits (Hanifah \& Purwanto, 2013). This function avoids possible financial difficulties. Setyowati \& Sari (2019) state that Operating Capacity has a negative significantly effect on financial distress. Total Assets Turnover (TATO) is a measure of operating capacity that shows a company's ability to generate profits based on its total assets. High asset turnover will accelerate the achievement of high profits as well (Chandra, 2020). Assets turnover have significant impact on profitability (Alarussi \& Alhaderi, 2018).

Profitability shows the success of the company in the final measure of the economy which is reflected in profits or earnings. Business viability cannot last long without profitability. A healthy company needs a balanced ratio of liquidity and profitability to maintain its viability for longer (Khan \& Raj, 2020). Companies that have high capabilities will increase profits and show that the company is successful and healthy so that it can compete with other companies (Kumalasari \& Ernawatiningsih, 2020). Profitability is a profit ratio measured by ROI (Return on Investment) or ROA (Return on Assets) which can significantly affect firm value. The fewer sources of financing through debt, the risk of debt is also low. (Kee et.al, 2021). Companies that have high profitability describe a good future for the company so that investors will give a positive response and the value of the company will be good (Dewi \& Novitasari, 2021). Liquidity has significant impact on profitability (Bibi \& Amjad, 2017). The 
result of previous study found that profitability have negative and significant impact on financial distress (Moch et.al, 2019; Masdupi et al., 2018; Ibrahim, 2017).

The company will experience financial difficulties first before going bankrupt seen from the uncertainty of the company's future profitability. (Utami \& Kawulur, 2020). In 1969, a researcher from the United States named Edward I. Altman, found a way of calculating to predict bankruptcy by combining several financial ratios with different weights between financial ratios. This financial distress (FD) method is called Altman Z-Score method. (Utami \& Kawulur, 2020). There are three types of Altman Z-Score bankruptcy prediction models, namely the first Altman model, the revised Altman model, and the modified Altman model. (Utami \& Kawulur, 2020).

The following hypotheses based on previous research are:

H1. Liquidity (LIQ) has a negative significantly effect on FD

$\mathrm{H} 2$. Leverage (LEV) has a positive significantly impact on FD

H3. Operating Capacity (OC) has a negative significantly impact on FD

H4. Profitability can mediate the relationship between LIQ and FD

H5. Profitability can mediate the relationship between LEV and FD

H6. Profitability can mediate the relationship between OC and FD

H7. Profitability (PROFIT) have significant impact on FD

\section{Methodology}

The population of this research is manufacturing companies listed on the Indonesia Stock Exchange (BEI) 2016-2018 with a total of 60 companies. The sample selection method uses a purposive sampling method with the qualifications of companies that publish financial reports for the period 2016 to 2018. The sample for this study consists of 123 data from 54 manufacturing companies listed on the IDX (Indonesia Stock Exchange) consisting of 28 consumer goods companies and 26 chemical companies.

This study uses three independent variables, one intervening variable and one dependent variable. The independent variables in this study are liquidity (LIQ), leverage (LEV), operating capacity (OC). The intervening variable in this study is profitability (PROFIT), while financial distress (FD) is the dependent variable. Liquidity is measured by the current ratio, which is the ratio of current assets to current debt. Leverage is measured by the debt to equity ratio, which is the ratio of total debt to total equity. Operating capacity is measured from total asset turnover which is the ratio of sales to total assets. Profitability is measured from return on assets which is the comparison of net income after tax to total assets.

Data analysis in this study used path analysis with Warp PLS 5.0 as an analytical tool. WarpPLS can describe indirect effects and total effects along with their values, effect sizes and standard errors. WarpPLS processing results can test the effect of the mediating variable path analysis using Warp PLS 5.0 software. PLS Warp can display total effect values and indirect values along with standard error, effect size and value. The results of these calculations are very helpful for testing mediating variables (Mediating / intervening variable). The use of paths in analyzing and testing data can show indirect or direct effects between variables. In addition, the use of paths in testing the data can show whether there is an influence of the mediating variable between the relationship between the independent variable and the dependent variable. This study also uses Sobel Test analysis to determine the significance of the existence of an intervening variable in mediating the indirect relationship between variables.

\section{Results and Discussion}

The result of descriptive analysis and fit model can be seen on Table 1 and table 2 as follows: 
Table 1 Descriptive statistics of the research variables

\begin{tabular}{|c|c|c|c|c|c|}
\hline & N & Min & Max & Mean & $\begin{array}{c}\text { Std. } \\
\text { Deviation }\end{array}$ \\
\hline LIQ & 123 & 0.08 & 8.64 & 2.24282 & 1.668693 \\
\hline LEV & 123 & -3.17 & 1.11 & 0.08503 & 0.329482 \\
\hline OC & 123 & 0.01 & 2.30 & 0.75925 & 0.404974 \\
\hline PROFIT & 123 & -2.10 & 5.27 & 0.49599 & 0.896782 \\
\hline FD & 123 & -6.20 & 6.95 & 0.62429 & 1.525790 \\
\hline N & 123 & & & & \\
\hline
\end{tabular}

Source: calculated using Warp PLS 5.0

Based on table 1 above shows the number of valid data are 123, from 123 financial distress (FD) sample data, the minimum value is -6.20 , the maximum value is 6.95 , from the $2016-2018$ period it is known that value of mean is 0.62429 , as well as the value deviation standard is 1.525790 , which means that the mean value is lower than the value of deviation standard, so the distribution of the value is evenly distributed. Liquidity (LIQ) of 123 samples, it explain the maximum value is 8.64 , the minimum value is 0.08 , the mean value is 2.24282 from $2016-2018$, and the standard deviation value is 1.668693 which means that the mean liquidity value for the 2016-2018 period is higher than the standard deviation value so data deviation is low, the value is evenly distributed. Leverage (LEV) from 123 samples, it describes the minimum value is -3.17 , the maximum value is 1.11 , the mean value is 0.08503 from 2016 until 2018, and the standard deviation value is 0.329482 , so the mean value for the 2016-2018 period is lower than the standard deviation value. Leverage has a high degree of data variation. Operating Capacity $(\mathrm{OC})$ of 123 samples, it shows the minimum value is 0.01 , the maximum value is 2.30 , the mean value is 0.75925 from $2016-2018$ period, and the standard deviation value is 0.404974 meaning that the mean operating capacity value for the 2016-2018 period is greater than the standard value deviation then data deviation is low, even though the value is evenly distributed. The profitability (PROFIT) of 123 samples have minimum value for -2.10 , the maximum value for 5.27 , the mean value is 0.49599 for 3 years period, and the standard deviation value is 0.896782 , which means that the mean value for the 2016-2018 period is lower than the standard deviation value. Profitability has a high level of data variation.

Table 2 Fit Model of Research

\begin{tabular}{|l|c|}
\hline \multicolumn{1}{|c|}{ Definition } & Conclusion \\
\hline coeff of avg path $(\mathrm{APC})=0.232, \mathrm{P}=0.002$ & Fit \\
\hline avg of R-square (ARS) $=0.353,=\mathrm{P}<0.001$ & Fit \\
\hline avg adj. of R-square $(\mathrm{AARS})=0.334,=\mathrm{P}<0.001$ & Fit \\
\hline avg block AVIF (VIF) $=1.343$, accepted if $<=5$, ideally $<=3.3$ & Fit \\
\hline avg full of coll. VIF $(\mathrm{AFVIF})=1.260$, accepted if $<=5$, ideally $<=3.3$ & Fit \\
\hline $\begin{array}{l}\text { tenenhaus of GoF }(\mathrm{GoF})=0.594, \text { large }>=0.36 \text {; medium }>=0.25 ; \\
\text { small }>=0.1\end{array}$ & Fit \\
\hline
\end{tabular}

Source: calculated using Warp PLS 5.0

Table 2 shows that the model or form of this research is fit. This explained by the AFVIF value of 1.260 and the AVIF value of 1.343 which is smaller than 3.3. It mean that there is no multicollinearity between exogenous variables and indicators. On the other hand, it looks the GoF value is 0.594 , so the prediction of the model is very large because it is greater than 0.36 . 
Table 3 Full Collinearity VIF, R Squared and Adjusted R squared test

\begin{tabular}{|c|c|c|c|c|c|}
\hline & LIQ & LEV & OC & PROFIT & FD \\
\hline Full collinearity & 1.193 & 1.051 & 1.173 & 1.554 & 1.329 \\
\hline R squared & & & & 0.380 & 0.326 \\
\hline R squared & & & & 0.380 & 0.326 \\
\hline
\end{tabular}

Source: calculated using Warp PLS 5.0

Results of table 3 above explain the affect profitability at $R$ squared is 0.380 , which means the impact of variations in Liquidity, Leverage, Operational Capacity ratio on Profitability of $38.0 \%$ and the remaining $62.0 \%$ is explained by other variables. The adjusted $R$ squared value for variations in the effect of Liquidity, Leverage, Operating Capacity, Profitability on Potential Bankruptcy in manufacturing companies as measured by an ROA of 0.326 or $32.6 \%$, the remaining $67.4 \%$ is influenced by outside variables.

Table 4 Path Coefficient and P-Value Results

\begin{tabular}{|c|c|c|}
\hline Path & Coefficient & P-value \\
\hline LIQ $\rightarrow$ FD & 0.107 & 0.114 \\
\hline LEV $\rightarrow$ FD & 0.245 & $0.002^{* * *}$ \\
\hline OC $\rightarrow$ FD & 0.059 & 0.254 \\
\hline PROFIT $\rightarrow$ FD & 0.304 & $<0.001^{* * *}$ \\
\hline LIQ $\rightarrow$ PROFIT & 0.286 & $<0.001^{\text {*** }}$ \\
\hline LEV $\rightarrow$ PROFIT & 0.214 & $0.007^{\text {***}}$ \\
\hline OC $\rightarrow$ PROFIT & 0.407 & $<0.001^{\text {*** }}$ \\
\hline
\end{tabular}

Source: calculated using Warp PLS 5.0

Table 4 explains the coefficient model of the path test and the number P. It show liquidity has a insignificant positively effect on FD (financial distress) in manufacturing companies. This is described by the liquidity coefficient value of 0.107 and a p-value of 0.114 , inconsistent with the hypothesis 1 , so the first hypothesis $(\mathrm{H} 1)$ is rejected. To test the second hypothesis $(\mathrm{H} 2)$, leverage has a positive and significant impact on financial distress in manufacturing companies, as known by the coefficient leverage value of 0.245 and $p$-value 0.002 , so the second hypothesis $(\mathrm{H} 2)$ is accepted. Furthermore, operating capacity with a coefficient value of 0.059 and a p-value of 0.254 where the third hypothesis $(\mathrm{H} 3)$, namely operating capacity has a negative and significant effect on financial distress in manufacturing companies, is rejected. To test the fourth hypothesis $(\mathrm{H} 4)$, namely profitability has a significantly and positive effect on financial distress in manufacturing companies, indicated by the profitability coefficient value of 0.304 and $p$-value $<0.001$, so the fourth hypothesis $(\mathrm{H} 4)$ is accepted.

Next is liquidity with a coefficient of 0.286 and a p-value of $<0.001$ where the fifth hypothesis (H5) that profitability can mediate the effect of liquidity on financial distress accepted. Furthermore, leverage with a coefficient value of 0.214 and $p$-value of 0.007 , where the sixth hypothesis is that profitability can mediate the effect of leverage on financial distress or bankruptcy in manufacturing companies is accepted. To test the seventh hypothesis, it shows that operating capacity has a coefficient value of 0.407 and a $p$-value $<0.001$, so the seventh hypothesis $(H 7)$ that profitability can mediate the effect of operating capacity on financial distress in manufacturing companies is acceptable.

The complete test model shows a causal relationship between variables which is illustrated in Figure 2 , in this case liquidity, leverage and operating capacity are not dependent variables and financial distress is the dependent variable mediated by profitability. 
Figure 2 Complete Test Model

Source: calculated using Warp PLS 5.0

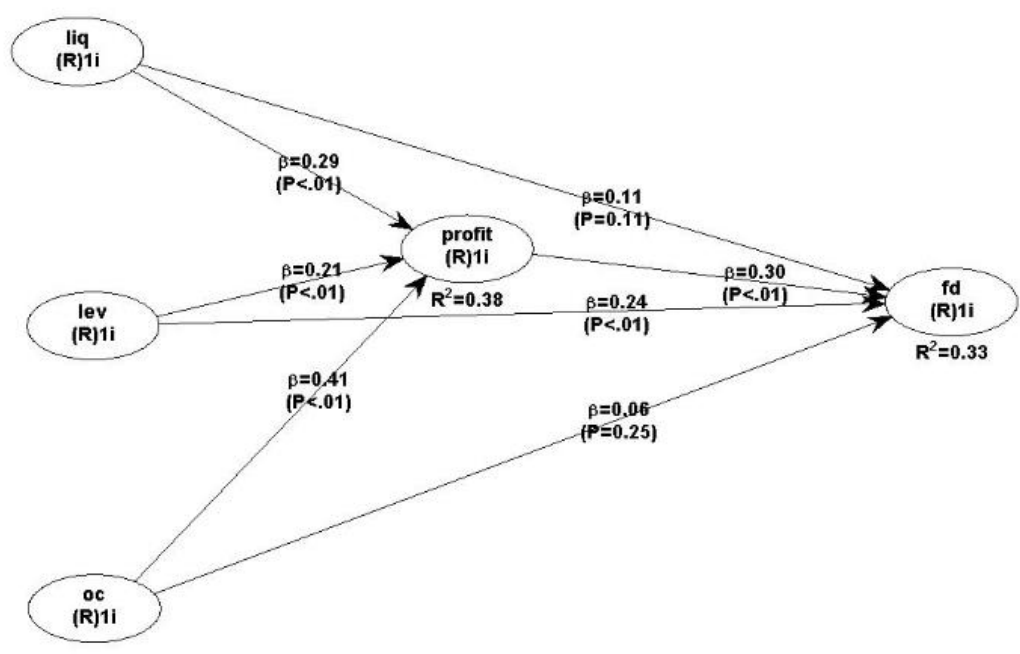

Table 5 Indirect Effect and Total Effect

\begin{tabular}{|l|c|c|}
\hline Indirect Effect & $\begin{array}{c}\text { Path } \\
\text { Coefficient }\end{array}$ & P Values \\
\hline LIQ -> PROFIT -> FD & 0.087 & $<0.001$ \\
\hline LEV -> PROFIT -> FD & 0.065 & 0.005 \\
\hline OC -> PROFIT -> FD & 0.124 & 0.026 \\
\hline Total Effect & $\begin{array}{c}\text { Path } \\
\text { Coefficient }\end{array}$ & P Values \\
\hline LIQ -> PROFIT -> FD & 0.194 & 0.013 \\
\hline LEV -> PROFIT -> FD & 0.310 & $<0.001$ \\
\hline OC -> PROFIT -> FD & 0.183 & 0.018 \\
\hline
\end{tabular}

Source: calculated using Warp PLS 5.0

According to effect of mediation results in table 5 , the coefficient of indirect effect for testing the LIQ->PROFIT->FD is 0.087 with $p$-value $<0.001$. The direct path relationship show that LIQ->FD is not significant at 0.114. Meanwhile, the LIQ->PROFIT direct relationship path is significant at the value $<0.001$. Likewise, the path of the direct relationship PROFIT- $>$ FD is significant at a value of $<0.001$, so there is a relationship between liquidity (LIQ) and financial distress (FD) through PROFIT as a partial mediating variable.

Furthermore, the coefficient of indirect effect coefficient to test hypothesis, namely LEV->PROFIT$>F D$ is 0.065 and the direct influence LEV->FD has a p-value of 0.005 which is significant. The result of direct path relationship LEV->FD is significant at 0.002 . While the direct relationship path LEV->PROFIT is significant at the value of 0.007 . Likewise, the direct relationship path PROFIT- $>$ FD is significant at a value of $<0.001$, so it explain that the leverage relationship (LEV) on financial distress (FD) through PROFIT as the full mediating variable.

The next test of the mediation effect is the number of the indirect effect relationship between OC$>$ PROFIT->FD of 0.124 and $p$-value of 0.026 . Furthermore, the direct path of operating capacity (OC) to financial distress (FD) are not significant at the value of 0.254 . Meanwhile, the direct relationship between operating capacity $(\mathrm{OC})$ and PROFIT is significant at $<0.001$. So it describe that there is a partial mediation on the relationship between operating capacity $(\mathrm{OC})$ and financial distress (FD) through profitability (PROFIT). 
Figure 3 Sobel test result of Liquidity Effect on Financial Distress through profitability

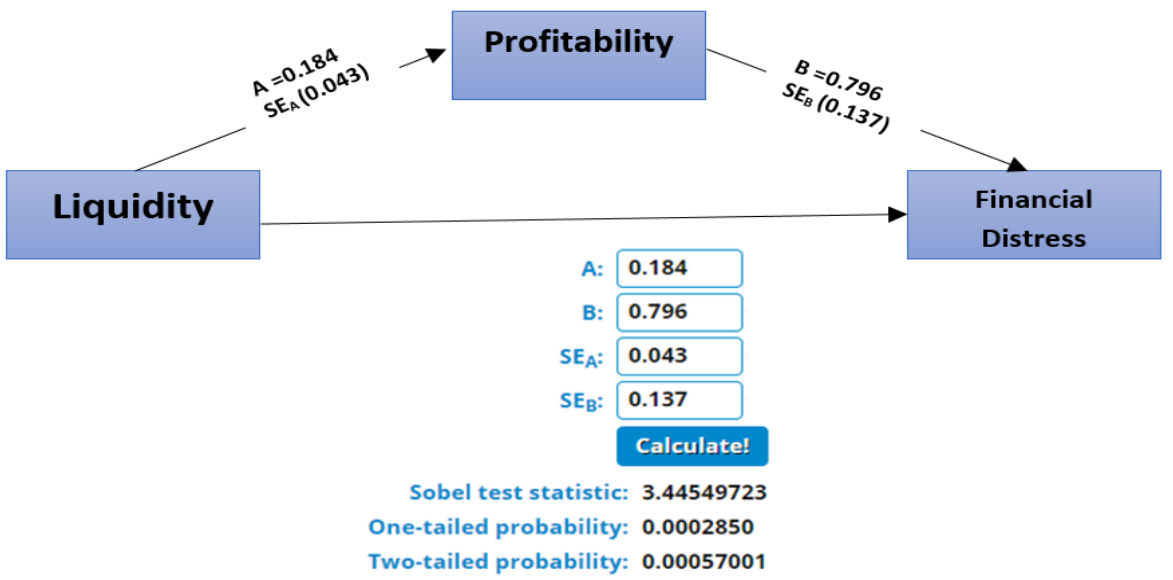

Source: calculated using Sobel Test

Sobel test tool serves to see the significant or insignificant role of the intervening variable in mediation relationship between variable $X$ and variable $\mathrm{Y}$. Based on the sobel test calculator in Figure 3 that the results of sobel test get a $z$ value of 3.44549723 , and significance value is $0.0002850<0.05$. It describes that profitability can mediate liquidity on financial distress significantly.

Figure 4 Sobel test result of Leverage Effect on Financial Distress through profitability

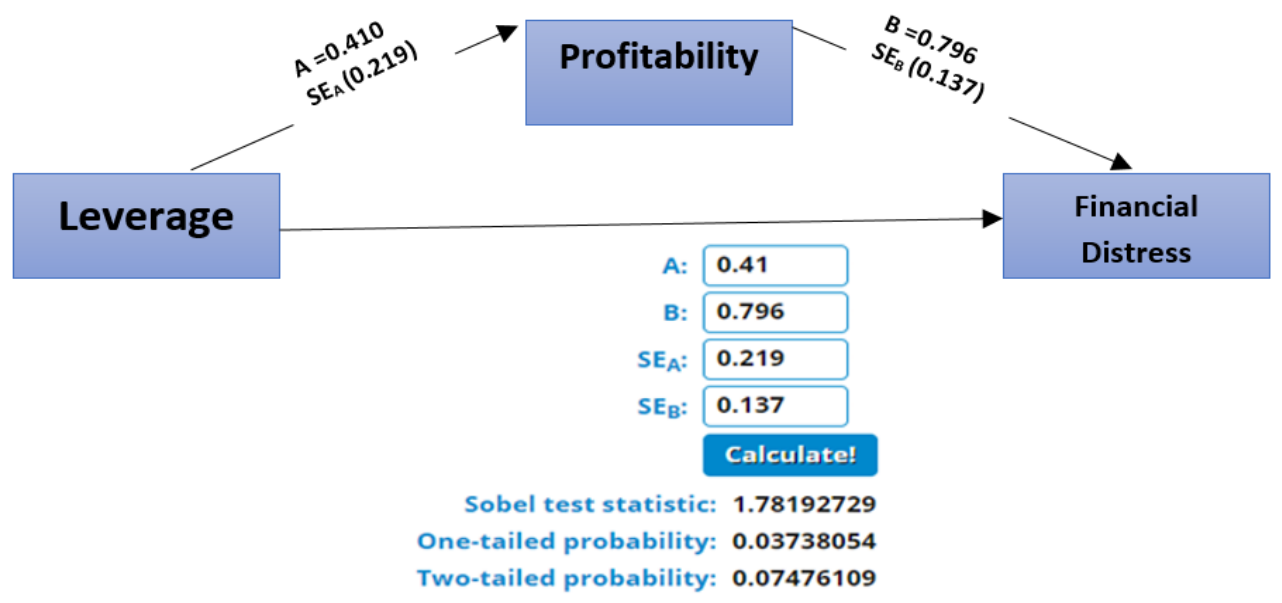

Source: calculated using Sobel Test

Figure 5 Sobel test result of Leverage Effect on Financial Distress through profitability

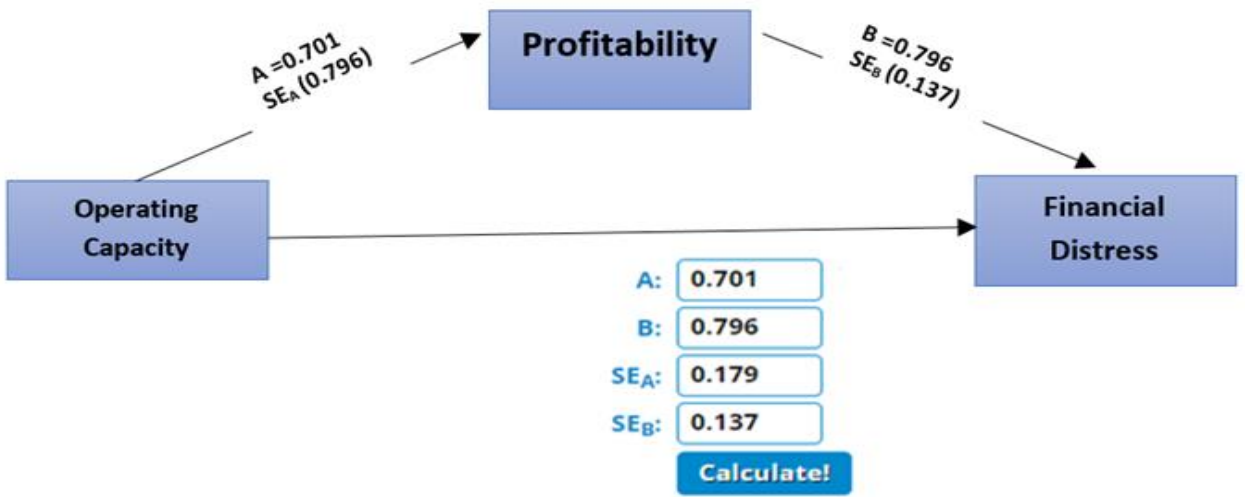

Sobel test statistic: $\mathbf{3 . 2 4 7 4 1 3 8 3}$

One-tailed probability: 0.00058229

Two-tailed probability: 0.00116459

Source: calculated using Sobel Test 
Based on the sobel test calculator in Figure 4 that the results of sobel test get a $z$ value of 1.78192729 , and significance value is $0.03738054<0.05$. It explains that profitability can mediate leverage on financial distress in significantly value.

Based on the sobel test calculator in Figure 5 that the results of sobel test get a $z$ value of 3.24741383 , and significance value is $0.00058229<0.05$. It can be concluded that profitability can mediate operating capacity on financial distress in significant results.

\section{Conclusion}

In this study, the variables that affect financial distress are leverage and profitability. Meanwhile, operating capacity and liquidity have no impact on financial distress. Otherwise, liquidity, leverage and operating capacity have significant effect on profitability in manufacturing companies. The result of intervening test found that profitability can mediate the influence of operating capacity, liquidity, and leverage variables on financial distress. According to Sobel test, profitability can mediate significantly the relationship between operating capacity, liquidity, and leverage with financial distress or bankruptcy. The most dominant variable affecting bankruptcy is profitability, while the leverage variable is the most dominant variable affecting profitability.

Recommendations for future research are the addition of a wider population variation for a more specific description of the effect of operating capacity, leverage, and liquidity on bankruptcy or financial distress with profitability as a mediating variable. In addition, it is necessary to do further research on other variables that affect financial distress using more diverse financial ratios such as return on equity, return on investment, and debt to assets ratio. The further research can use another object research such as insurance company, banking or other companies. Suggestions for anticipating bankruptcy is to perform operational cost efficiency so that profitability will be high and the risk of bankruptcy will be low.

\section{References}

1. Ahmad, N., Salman, A., \& Shamsi, A. F. (2015). Impact of Financial Leverage on Firms' Profitability : An Investigation from Cement Sector of Pakistan. Research Journal of Finance and Accounting, 6(7), 75-81.

2. Alarussi, A. S., \& Alhaderi, S. M. (2018). Factors affecting profitability in Malaysia. Journal of Economic Studies, 45(3), 442-458. https://doi.org/10.1108/JES-05-2017-0124

3. Almilia, Luciana Spica. \& Kristijadi. (2003). Financial Ratio Analysis for Predicting Condition of Company Financial Distress Manufacturing Listed on Stock Exchange Jakarta. Indonesian Journal of Accounting and Auditing (JAAl), 7(2), 183-210.

4. Amanda, Yola. \& Tasman, Abel. (2019). Effect of Liquidity, Leverage, Sales Growth and Company Size on Financial Distress in Manufacturing Companies Listed on the Indonesia Stock Exchange (IDX) Period 2015-2017. EcoGen Journal, 2(3), 453-462.

5. Antikasari, Tiara Widya. Djuminah. (2017). Predicting Financial Distress with Binary Logit Telecommunication Company Regression. Journal of Finance and Banking, 21(2), 265-275.

6. Ardianto, FD \& Prasetiono. (2011). Prediction of Financial to Financial Distress Condition of Manufacturing Companies Listed in IDX. Journal of Economic Dynamic, 1(11).

7. Bibi, N., \& Amjad, S. (2017). The Relationship between Liquidity and Firms' Profitability: A Case Study of Karachi Stock Exchange. Asian Journal of Finance \& Accounting, 9(1), 54. https://doi.org/10.5296/ajfa.v9i1.10600

8. Brigham \& Houston. (2014). Basics of Financial Management. Edition 11. Salemba Empat. Jakarta.

9. Chandra, S. (2020). Effects of Long Term Debt to Total Assets, Short Term Debt to Total Assets, Total Asset Turnover, and Inventory Turnover on Profitability of Manufacturing Companies in Consumer Goods Subsector Listed on IDX. Journal of Applied Business and Technology .1(3), 212-222. 
10.Cinantya, I Gusti AGung A.p \& Merkusiwati, Ni Ketut Lely A. (2015). Corporate Governance, Financial Effect Indicators and Company Size on Financial Distress. E-Accounting Journal of Udayana University, 10(3), 897-915.

11.Dalci, I. (2018). Impact of financial leverage on profitability of listed manufacturing firms in China. Pacific Accounting Review, 30(4), 410-432. https://doi.org/10.1108/PAR-01-2018-0008.

12.Dewi, Ni Luh Putu Sandrya., \& Novitasari, Ni Luh Gde. (2021). Effect of Return on Assets and Company Growth on Company Value (A Case Study of Manufacturing Companies Listed on Indonesia Stock Exchange). International Journal of Accounting \& Finance in Asia Pasific (IJAFAP), 4(2), 1-11.

13.Dianova, Agustina. \& Nahumury, Joicenda. (2019). Investigating The Effect of Liquidity, Leverage, Sales Growth and Good Corporate Governance on Financial Distress. Journal of Accounting and Strategic Finance, 2(2), 143-156.

14.Erni. \& Imron, Moch. (2019). Financial Ratio Analysis for Predicting Financial Distress Conditions at Islamic Commercial Banks and Islamic People's Financing Bank. University of Ahmad Dahlan, eprints.uad.ac.id., 58-77.

15. Hidayat \& Meiranto. (2014). Prediction of Financial Distress of Manufacturing Companies in Indonesia. Journal of Diponegoro Accounting, 3(2), 1-11.

16.Ibrahim, S. S. (2017). The Impacts of Liquidity on Profitability in Banking Sectors of Iraq. International Journal of Finance \& Banking Studies (2147-4486), 6(1), 113-121. https://doi.org/10.20525/ijfbs.v6i1.650

17.Jamal \& Shah. (2017). The impact of Corporate Governance on the cost of equity: Emperical Evidence from pakistan listed Companies. Jinnah business review, 5(2), 49-53.

18.Kartika, Rizky. \& Hasanudin. (2019). Analysis of Influence of Liquidity, Leverage, Activity, and Profitability Against Financial Distress in Infrastructure Sector Open Company, Utility, and Transportation for the Period of 2011-2015. Journal of Management Science, 15(1), 1-16.

19.Kee, Daisy Mui Hung., Juseef, Nur Shaidah., Halim, Nur Nabilah., Nafisah, Nur., Sorfina, Nur. (2021). Analysis of Financial Performance: 7ELEVEN SDN. BHD. International Journal of Accounting \& Finance in Asia Pasific (IJAFAP), 4(2), 23-32.

20.Khan, M. M., \& Raj, K. B. (2020). Liquidity-profitability analysis \& prediction of bankruptcy - A study of select telecom companies. Journal of Critical Reviews, 7(3), 307-316.

https://doi.org/10.31838/JCR.07.03.62

21.Kumalasari, Putu Diah, \& Ernawatiningsih, Ni Putu Lisa. (2020). The Determinants of Profitability in Village Credit Institution. International Journal of Accounting \& Finance in Asia Pasific (IJAFAP), 3(1), 41-45.

22.Lumapow, Lihard Stevanus \& Tumiwa, Ramon Arthur Ferry. (2020). Working Capital and Debt Policy on Profitability of The Companies. International Journal of Accounting \& Finance in Asia Pasific (IJAFAP), 3(2), 26-36.

23.Maharani, T., \& Fuad, K. (2020). The Effect of Human Capital, Structural Capital, Customer Capital, Managerial Ownership, and Leverage Toward Profitability of Company. Journal of Advanced Multidisciplinary, 1(1), 46-62.

24.Masdupi, E., Tasman, A., \& Davista, A. (2018). The Influence of Liquidity, Leverage and Profitability on Financial Distress of Listed Manufacturing Companies in Indonesia. 57 (Piceeba), 223-228. https://doi.org/10.2991/piceeba-18.2018.51

25.Pulungan. (2017). The Effect of Liquidity and Leverage on Financial Distress in The Ceramics SubSector Listed on the IDX. Journal of financial accounting, 3(2),1-9.

26.Putri, Ni Wayan Krisnayanti. A \& Merkusiwati, Ni Kt.Lely A. (2014). The Effect of Corporate Governance Mechanism, Liquidity, Leverage, and Company Size on Financial Distress. E-Accounting Journal of Udayana University, 7(1), 93-106.

27.Putri, Sonia N.A \& Puryandani, Siti. (2020). The Influence of Cash Flow, Leverage and Profitability on Investment Decisions in Financial Distress Companies (All Companies Listed on Indonesia Stock Exchange of 2017-2019). Proceedings of the $3^{\text {rd }}$ International Conference of Banking, Accounting, 
Management and Economics (ICOBAME-2020), Advances in Economics, Business and Management Research, volume 169 (pp.447-452). Atlantis Press Publisher.

28.Moch, Rusli. Prihatni, Rida. \& Buchdadi, Agung Dharmawan. (2019). The Effect of Liquidity, Profitability and Solvability to The Financial Distress of Manufactured Companies Listed on The Indonesia Stock Exchange (IDX) Period of Year 2015-2017. Academy of Accounting and Financial Studies Journal, 23(6).

29.Saputri, Lilis \& Asrori. (2019). The Effect of Leverage, Liquidity and Profitability on Financial Distress with the Effectiveness of the Audit Committee as a Moderating Variable. Accounting Analysis Journal, 8(1), 38-44.

30.Setyowati, Widhy. \& Sari, Nadya Ratna N. (2019). Influence of Liquidity, Operating Capacity, Company Size and Sales Growth on Financial Distress (Study on Manufacturing Companies Listed on the Stock Exchange 2016-2017). Journal of Magisma, 7(2), 135-146.

31.Taurista, Ditarosa. Fatimah, Mustika Putri, \& Mubarrok, M.Khusni. (2018). Analysis Dominant of Factors Influence in Decline Company Liquidity. International Journal of Accounting \& Finance in Asia Pasific (IJAFAP), 1(1), 58-67.

32.Utami, Desi, \& Kawulur, Hisky Ryan. (2020). Analysis of Bankruptcy Prediction by Altman Z-Score Modification (Study at PT BPR Primaesa Sejahtera Kota Manado. International Journal of Applied Business and International Management (IJABIM), Students edition, 8-15.

33.Zhafirah, Anindya. \& Majidah. (2019). Analysis of Determinants of Financial Distress (Empirical Study on Companies Textile and Garment Subsector Period 2013-2017). Journal of Accounting and Finance Research, 7(1), 195-202. 